Open Access

\title{
The flipped classroom model at the university: analysis based on professors' and students' assessment in the educational field
}

\author{
Òscar Flores", Isabel del-Arco and Patricia Silva
}

* Correspondence:

oscar.flores@udl.cat

Department of Pedagogy and Psychology at the Faculty of

Education, Psychology and Social Work, University of Lleida (UdL),

Lleida, Spain

\begin{abstract}
We find ourselves in the era of a new paradigm of education, in which learning ceases to be an internal and individual activity and becomes an activity performed collectively, critically, in participation with others, and online (Siemens, 2005). It is in this sense that the flipped classroom model arises. The present study provides evidence of the model's efficacy at the university. The study investigates whether the model improves: the teaching and learning processes, the satisfaction in the development of the course, the academic performance of students and the assessment of professors. The method used consisted of an evaluative study and the collection of data from both professors and students. Regarding students, we analysed the following set of data: academic results, the university's official survey, a questionnaire created and validated for the purpose of this study, and a focus group. Regarding professors, we collected data by interviewing the professors that organized the course. The results were in line with the previous study carried out by Yarbro, Arfstrom, McKnight and McKnight (2014). The study by Yarbro and colleagues, as well as present study, confirmed that the model contributed to: the enrichment of teaching and learning processes, aspects related to the integration of concepts, the role change of professors and students, the improvement of the processes of participation and communication, the integration of the ICTs, the improvement of academic results, and the promotion of student interest in the course.
\end{abstract}

Keywords: Flipped classroom, University teaching, Teaching innovation, Education

\section{Introduction}

Innovative education: to 'flip' the classroom

We live in a society that embraces diverse, global, digital and hypertextual knowledge. The Internet and the digital world have brought about radical change in the way knowledge is accessed and transmitted. Learning has ceased to be an internal and individual activity, and has become an activity performed collectively, online (Siemens, 2005).

True innovation in the classroom will depend on how it is designed, as the aim is to "educate technology rather than digitalizing the classroom" (Prensky, 2010). Education needs to undergo a change, in which the professor is no longer seen as the center of the formative process, or as the source of fragmented and uninspiring knowledge.

(C) 2016 Flores et al. Open Access This article is distributed under the terms of the Creative Commons Attribution 4.0 International License (http://creativecommons.org/licenses/by/4.0/), which permits unrestricted use, distribution, and reproduction in any medium, provided you give appropriate credit to the original author(s) and the source, provide a link to the Creative Commons license, and indicate if changes were made. 
The new paradigm positions students in the center of the process, with models that stimulate their curiosity, creativity, abilities, teamwork, and knowledge acquired outside the classroom. Additionally, the resources have been already created and can be found online. All it needs is for the professors to make the materials available to students. Once that is done, students are expected to work, analyze, and interpret the material, and even improve it. In a nutshell, this new paradigm aims to change the role of the professor, and turn the professor into a figure that spends less time explaining and more time stimulating, advising, and supporting students.

The flipped classroom is based on a model that reorganizes the time in and outside the classroom. The model is part of a wider pedagogical movement that overlaps with blended learning, learning based on research, and with those approaches that promote active participation of students and flexibility within educational processes.

Jonathan Bergmann and Aaron Sams developed the model in 2006 in the Secondary School of Woodland Park, Colorado, where both worked as teachers (Bergmann and Sams, 2014). The concept has evolved since, and it has given way to a methodology that goes beyond the mere substitution of the classic lecture for a video (Carballo, 2014).

Nowadays, the flipped classroom offers more opportunities for students to develop critical and independent thinking, and for students to enhance their own learning processes by interacting collaboratively with peers. Further, professors give more flexibility and freedom to students so they can learn from activities specially designed to enhance their problem-solving skills.

\section{Evidence on the efficacy of the model}

The present study can be linked to the following authors and their approaches as they present similar perspectives of the topic in question. These authors and approaches are: Moraros, Islam, Yu, Banow, and Schindelka (2015) and Blair, Maharaj, C, and Primus (2015), who analyze the flipped classroom and describe it as the action that helps students to improve their academic results; Abeysekera and Dawson (2015) who look into what can be changed in traditional education in order to ultimately substitute it for an education with more active methodologies; and Rivera (2015), who highlights the importance of training efficient time management.

Further, another aspect that validates the current model's efficacy is the report, Flipped Learning Network (2012), which presents and analyzes some of the results of applying the model. The report shows that from the 453 professors that applied the flipped classroom, $67 \%$ perceived an improvement on the academic results of their students, $80 \%$ noticed an improvement on the attitude of their students, and $99 \%$ stated that would "flip" their classrooms again.

Another interesting contribution to this list of evidence comes from Clintondale High School in Michigan, where the failure rate of its $9^{\text {th }}$ grade students in the mathematics class dropped from 44 to $13 \%$ after applying the flipped classroom model (Finkel, 2012).

Additionally, we want to highlight the report drafted by Yarbro, Arfstrom, McKnight, and McKnight (2014), which collects data on varied case studies in which the model was applied throughout different periods and levels of education. The results suggest that the performance of students improved and both teachers and students were more satisfied with the teaching process and outcomes. 
In short, evidence of the efficacy of the model and its advantages are gradually appearing (Tourón \& Santiago, 2015). However, the results of these publications are not conclusive and, thus, they cannot be used to establish that the model is effective (Goodwin \& Miller, 2013).

Nevertheless, everything suggests that the model does improve the academic performance of students as well as their engagement with the learning process. The student ceases to be a passive element and develops key competencies such as: selection of information, teamwork, critical thinking, and self-management and self-assessment of the learning process.

Additionally, the teacher mediates, offers support, and guides. That is, the flipped classroom model gives the teacher more flexibility to offer learning opportunities based on problem-solving activities, which aim to give confidence and orientation to the student (Del Arco \& Camats, 2015).

In conclusion, the present study aims to add on the data of the experts mentioned above. Further, by knowing the effects of the flipped classroom on academic training, and comparing this data to those from existing studies, we provide further evidence about this model's efficacy.

\section{Planning and implementation of the flipped classroom}

The first key element that ensures the success of the process is the development of a wellorganized teaching plan, which specifies the activities that will be carried out, as well as the resources and contents that will be consulted (Flores, 2015). In this way, the student: will have a clear idea of the work schedule; will be able to locate the material needed on the resources provided; and, will know when he/she is required to do the different activities. A detailed and explicit plan will result in a decrease of the student's anxiety and in an increase of his/her confidence regarding the working methodology (Fig. 1).

Another important element is centralizing the working space for students when they are not in the classroom. A good strategy is to use the virtual campus of the university for this purpose, as it allows for:

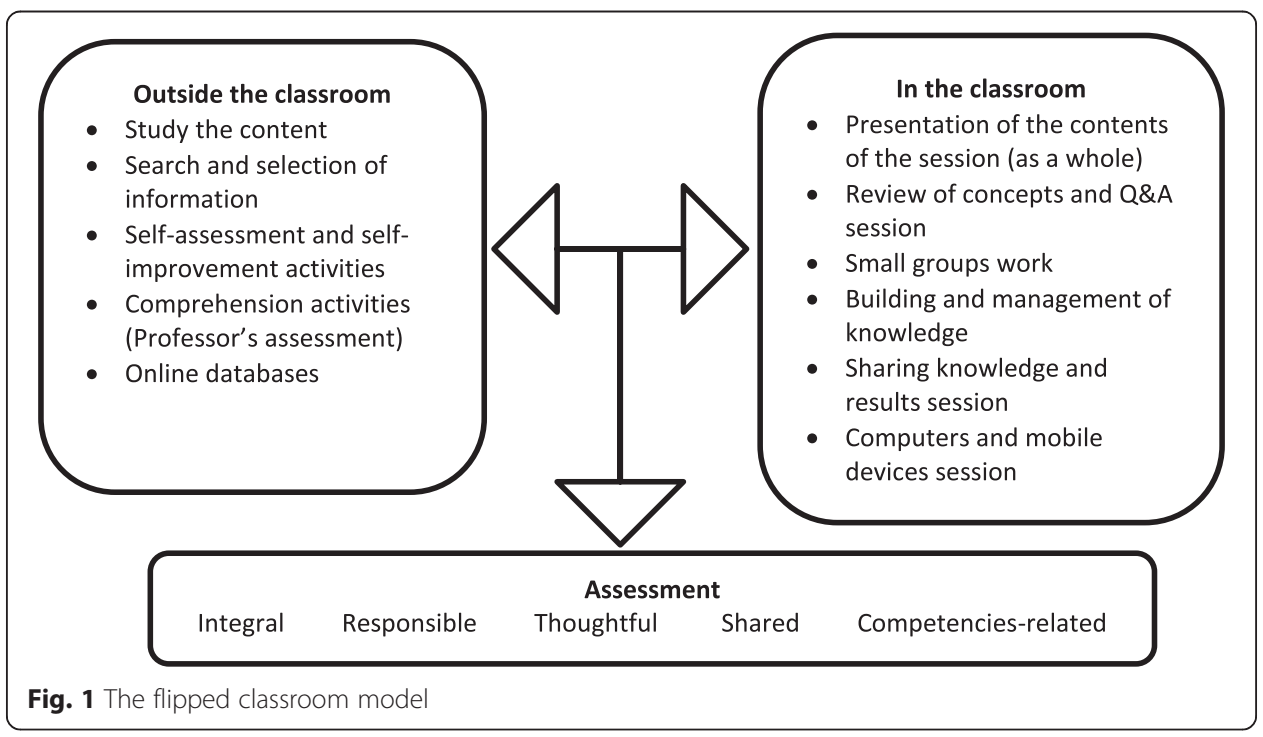


- Organizing the contents in different units according to the program.

- Offering resources in different formats (textual, graphic, audiovisual, links to webpages, etc.)

- Developing multiple choice question activities that offer opportunity for selfassessment, while that limiting or approving the progression of the student in the course depending on performance.

- Suggesting comprehension activities assessed by the teacher.

- Establishing online forums that function as collaborative spaces of common reflection, where students will share resources, ask and solve questions, or analyze topics at hand related to the course.

Additionally, the collaborative work in and outside the classroom is a key element on the implementation of the flipped classroom. The student builds his/her knowledge interacting and cooperating with peers both in the classroom and in the online space (Shea \& Bidjerano, 2010; Shea et al., 2012).

In face-to-face classes, the professor can devote the first part of the class to reviewing the contents of the course, which can serve as an introduction to the practical work that students will carry out during the class. For this practical work, the students will be divided into small groups and the professor will help each group to carry out the activity. Upon completion of the activity, each group shares what has been learnt with the rest of the class, and then, the students discuss the solutions and results proposed by each group. The activity can end with a reflection about the competencies that the student developed during the activity.

Moreover, with this model, students can use laptops and mobile devices, as the faceto-face class activities may require searching information on the Internet. Therefore, with regards to the debate on whether or not technologies should be used in the classroom (Navarro, 2013), our position is to accept them and normalize their usage.

Finally, regarding the assessment process, we aim to develop a type of continuous assessment throughout the academic year. The goal is to achieve a type of assessment that advances in juxtaposition with the learning process, which raises relevant questions among students while also encouraging them to learn from their mistakes (Tourón, Santiago, \& Diez, 2014).

As seen in Fig. 1, and according to our implementation experience, we consider that this type of assessment must be as follows:

- Integral, i.e. that encompasses the work carried out both in and outside the classroom.

- Responsible, i.e. that lets the students carry out part of the assessed activities outside the classroom without the direct guidance of the professor.

- Thoughtful, i.e. that analyzes and synthesizes the information.

- Shared, i.e. that includes co-assessed activities among students, which promote a cooperative and co-responsible learning.

- Competence-related, i.e. that includes theoretical and practical activities that do not rely on the student's memory, but rather on his/her practical problem-solving skills.

\section{Description and aims of the study}

The study presented in this paper is based on the experiences from a face-to-face course worth 6 ECTS credits from the Master's in Psychopedagogy in the University of 
Lleida (UdL). The aim of the study is to show evidence of the efficacy of the model by analyzing different elements, namely:

- The opinion of students on whether or not the teaching and learning processes have improved.

- The degree of satisfaction of students in the course.

- The academic performance of students.

- The opinion of professors on the educational process.

\section{Method}

For the purpose of this study we carried out an evaluative investigation based on different theories and methodologies that range from classic theories, such as those proposed by Stufflebeam and Shinkfield (1987), to current theories, such as those proposed by Arthur and Cox (2014). In order to reach our goals we used quantitative and qualitative research methods (Greene, 2007). That is, we assessed the design and implementation of the flipped classroom model with quantitative techniques in order to later analyze and verify the results with qualitative techniques.

During the first phase we used the following data collection instruments:

a) The Official Survey from the University of Lleida Office of Quality (ENCUDL): this instrument consists of a series of items that assess the course and the professors' performance. For instance, students were asked to give their opinions about the course contents, the usage of resources during the learning process, or their overall satisfactions with regards to the course. Out of the 33 students that were listed for the course, 19 took the survey.

b) Course Survey (CUES): this instrument was designed $a d$ hoc and was validated by experts on the matter. In this case, students were asked to assess the course and the education model used, i.e. the flipped classroom model. More specifically, the survey consisted of: 3 identification items, 15 statements in which the student had to indicate his/her degree of agreement, and 2 open-answer questions. The survey was organized according to the following five-dimensional analysis: i) Integration of concepts; ii) the role of professors and students; iii) the integration of ICTs into the learning process; iv) the participation and communication in the classroom; and v) the interest shown in the course. Out of the 33 students that were listed on the course, 26 took the survey.

c) Analysis of academic results: we carried out a longitudinal comparative study between the academic results obtained by students of three different academic years. From the academic year 2013-2014, we obtained and reviewed the academic results of 38 students, from the academic year 2014-2015, 33; and from the academic year 2015-2016, 30.

Upon collection of the data with the mentioned instruments, we proceeded to complete the study by using two qualitative data collection instruments: a discussion group constituted by 8 students from the (GD) course and an unstructured interview with the professor of the course (EN). 
The data collected with the instruments was analyzed using a process combining descriptive statistics and qualitative categorization. This allowed us to observe to what extent the model improved the performance and satisfaction of students and faculty as well as the students' academic results.

\section{Results}

With regards to the Official Survey from the University of Lleida (ENCUDL), the results show a high percentage of student satisfaction with the course. Further, it is worth highlighting that in the results sheet, the figures appear side by side with the overall figures of the department, the school, and the university (Table 1).

Additionally, this instrument allows the student to write comments about the professor or about the course. In both instances, the comments were very positive:

"The professor has an in-depth knowledge of the contents of the subject and he is able to pass on his training and his teaching skills to students. Additionally, he cares about students and their performances and provides useful material."

(EST1-ENCUDL)

Table 1 UdL's Official Survey

\begin{tabular}{|c|c|c|c|c|}
\hline \multicolumn{5}{|l|}{ Master's survey } \\
\hline \multirow[t]{2}{*}{ 1. Professor(s) } & \multirow[b]{2}{*}{ Average } & \multicolumn{3}{|c|}{$\begin{array}{l}\text { Differences with respect } \\
\text { to the average }\end{array}$} \\
\hline & & Dept. & School & UdL \\
\hline 1. Presents the material clearly and systematically. & 4.58 & 0.93 & 0.81 & 0.70 \\
\hline 2. Provides resources that facilitate the learning process. & 4.89 & 1.28 & 1.17 & 1.04 \\
\hline 3. My overall assessment of the professor is satisfactory. & 4.68 & 0.97 & 0.84 & 0.71 \\
\hline \multirow[t]{2}{*}{ 2. Course - frequently asked questions } & & \multicolumn{3}{|c|}{$\begin{array}{l}\text { Differences with respect } \\
\text { to the average }\end{array}$} \\
\hline & Average & Dept. & School & UdL \\
\hline 10. The formative activities were as expected. & 4.21 & 0.79 & 0.65 & 0.57 \\
\hline $\begin{array}{l}\text { 11. The formative activities were open and allowed for } \\
\text { participation. }\end{array}$ & 4.84 & 1.25 & 1.02 & 0.94 \\
\hline $\begin{array}{l}\text { 12. The acquired competencies will be useful for my } \\
\text { professional career. }\end{array}$ & 4.32 & 0.70 & 0.59 & 0.58 \\
\hline 13. The course followed the scheduled program. & 4.68 & 0.70 & 0.63 & 0.80 \\
\hline $\begin{array}{l}\text { 14. The material provided was adequate and useful for } \\
\text { the purpose of the course. }\end{array}$ & 4.58 & 0.81 & 0.70 & 0.76 \\
\hline 15. My overall assessment of the course is positive. & 4.63 & 0.97 & 0.82 & 0.78 \\
\hline Summary & Course/Group & Dept. & School & UdL \\
\hline Number of survey sheets: & 19 & 194 & 155 & 421 \\
\hline Participation percentage: & $58 \%$ & $61 \%$ & $64 \%$ & $64 \%$ \\
\hline \multirow[t]{2}{*}{ Number of participants (professors/group-class): } & 19 & & & \\
\hline & & \multicolumn{3}{|c|}{$\begin{array}{l}\text { Differences with respect } \\
\text { to the average }\end{array}$} \\
\hline Professor(s) (average) & 4.72 & 1.06 & 0.94 & 0.82 \\
\hline Course - frequently asked questions (average) & 4.54 & 0.87 & 0.73 & 0.74 \\
\hline
\end{tabular}


"The contents are well-delimited and structured. The professor uses an innovative methodology and shows enthusiasm in order to motivate students and enhance their performance. We need more teachers like that in the university." (EST5-ENCUDL)

With regards to the Course Survey (CUES), and the quantitative and qualitative items, the students' responses were very positive. The following are some of the examples that best show those favorable responses:

First, regarding of integration of concepts (Table 2), a high percentage of students agreed on the fact that the working methodology helped them to better integrate the course contents.

Moreover, regarding the change in roles of both professors and students (Table 3), the majority of the students realized that roles did change within the model.

Likewise, regarding the integration of ICTs (Table 4), the majority of students agreed on the fact that the model favors the usage of ICTs in the classroom.

Further, another of the aspects that the majority of the students agreed upon was the fact that the model favors and enhances participation and communication between students and professors (Table 5).

Finally, Table 6 shows the students' degree of interest in the course. As can be observed, at the beginning of the academic year, the course generated great expectations among students. Further, by looking at the responses for the second item, those expectations were maintained and fulfilled throughout the academic year until completion of the course.

In line with the comments received in the Official Survey, the comments in the Course Survey showed a positive tendency:

"I want to specially highlight the professor's closeness and the quality of his teaching. I believe that others should follow his example of good practice in the methodology of the course and beyond." (EST6-CUES)

"The methodology of this course allows for: (1) studying at one's own pace, which reduces students' pressure and allows them to study in a much more relaxed and motivated way; (2) easy access to the contents of the course; (3) collaborative teamwork; (4) accurate assessment process, which not only makes students learn enough to pass the course, but also and most importantly, it makes them acquire new knowledge and skills; (5) In my opinion, this is a class experience that should be repeated and generalized." (EST19-CUES)

Table 2 Integration of concepts

\begin{tabular}{|c|c|c|c|c|}
\hline Dimension 1. Integration of concepts & Strongly agree & Agree & Disagree & $\begin{array}{l}\text { Strongly } \\
\text { disagree }\end{array}$ \\
\hline $\begin{array}{l}\text { To be able to access the course materials through } \\
\text { the Virtual Campus and work on them at my own } \\
\text { pace helped me to better integrate the course } \\
\text { contents. }\end{array}$ & $21(80.8 \%)$ & $4(15.4 \%)$ & $1(3.8 \%)$ & $0(0 \%)$ \\
\hline $\begin{array}{l}\text { I believe that I better integrated the course concepts } \\
\text { because I followed the parameters of a non-traditional } \\
\text { formative model. }\end{array}$ & 18 (69.2 \%) & $7(26.9 \%)$ & $0(0 \%)$ & $1(3.8 \%)$ \\
\hline
\end{tabular}


Table 3 Change in the role of professors and students

\begin{tabular}{lcccc}
\hline Dimension 2. Change in the role of professors and students & Strongly agree & Agree & Disagree & $\begin{array}{l}\text { Strongly } \\
\text { disagree }\end{array}$ \\
\hline $\begin{array}{l}\text { This model does change the role of the professor } \\
\text { (before he/she was an information deliverer and }\end{array}$ & $21(80.8 \%)$ & $5(19.2 \%)$ & $0(0 \%)$ & $0(0 \%)$ \\
now is a learning facilitator) & & & \\
$\begin{array}{l}\text { This model does change the role of the student } \\
\text { (before he/she was an information receiver and } \\
\text { now he/she builds his/her own knowledge) }\end{array}$ & $18(69.2 \%)$ & $8(30.8 \%)$ & $0(0 \%)$ & $0(0 \%)$ \\
\hline
\end{tabular}

With regards to the academic results, Table 7 is a comparative chart that shows the final grades of the course obtained during three consecutive academic years: 2013-2014, 2014-2015, and 2015-2016.

The following section collects and summarizes the most relevant responses obtained through the discussion group (DG).

- Integration of concepts: students realized that they had to keep reviewing the contents during the course in order for the model to work. However, students criticized that professors overly repeated what students had to read at home. Finally, students highly valued the fact that they had integrated the contents of the course, not only through learning the theory, but also through the practical work carried out.

- The changing role of professors and students: students valued the role changes during the development of the course. Further, students confirmed the fact that by changing roles, the professor becomes a guide, which allows students the opportunity to build their own knowledge. However clear the role changing turns out to be during and at the end of the course, the survey reveals that, at the beginning of the course, students did not understand the method clearly. It is in this sense that students highlighted the importance of building a climate of trust between students and professor.

"The first day I was a little bit confused. However, the confusion disappeared as a climate of trust was progressively built.” (EST2-GD)

- Integration of ICTs: students valued that the course contents were available on the virtual campus (in different formats).

"It was very useful to have the course materials on the campus, not only in text format, but also in others." (EST5-GD)

Further, two other aspects worth highlighting were: the positive usage of self-assessed tests in order to evaluate the degree of integration of concepts; and the fact that the university has a fast WiFi network, which facilitates working on the internet.

Table 4 ICTs integration

\begin{tabular}{lllll}
\hline Dimension 3. Effective integration of the ICTs & Strongly agree & Agree & Disagree & Strongly disagree \\
\hline $\begin{array}{l}\text { I believe that this model effectively integrates } \\
\text { the ICTs in the learning process. }\end{array}$ & $14(53.8 \%)$ & $11(42.3 \%)$ & $1(3.8 \%)$ & $0(0 \%)$ \\
\hline
\end{tabular}


Table 5 Participation and communication

\begin{tabular}{lcccc}
\hline Dimension 4. Participation and communication & Strongly agree & Agree & Disagree & $\begin{array}{l}\text { Strongly } \\
\text { disagree }\end{array}$ \\
\hline This model favors the active participation of students. & $19(73.1 \%)$ & $7(26.9 \%)$ & $0(0 \%)$ & $0(0 \%)$ \\
$\begin{array}{l}\text { This model favors communication between students } \\
\text { and professors. }\end{array}$ & $17(65.4 \%)$ & $9(34.6 \%)$ & $0(0 \%)$ & $0(0 \%)$ \\
$\begin{array}{l}\text { This model favors communication among students. } \\
20(76.9 \%)\end{array}$ & $5(19.2 \%)$ & $1(3.8 \%)$ & $0(0 \%)$ \\
\hline
\end{tabular}

- Participation and communication: students valued working in teams. They even mentioned the possibility of working even more collaboratively by meeting up with other groups or exchanging participants from one group to another.

"I would have enjoyed knowing more about what other groups were doing. I also think that the work would have been even better if the groups had met up or exchanged participants." (EST1-GD)

- Interest in the course: the comments of the survey confirmed an increase of interest in the course, which also indicates that students were motivated to attend class.

"Every Thursday I would feel less pressured than other days because I had this course and not others..." (EST1-GD)

Finally, the last element that was valued positively by students was the fact that the course did not result in a work overload outside the classroom.

The following section finally collects and summarizes the professors' assessment of the course obtained through interviews (EN):

- Integration of concepts: in line with the opinions expressed by students, the team of professors pointed out the fact that it was necessary that students read the materials. In fact, they stated that it was easy to tell who of the students had been reviewing the contents and who had not. Additionally, they admitted that it had been a mistake to overly repeat what students had to read for class at home. "Indeed, it seems that overly repeating what students need to do 'rewards' those who have not looked at the materials yet, and 'punishes' those who have already done it. We will certainly take this consideration into account in future academic years." (EN-PROF1)

- The changing role of professors and students: professors expressed the difficulties of changing the roles. One reason for this might be that culturally, in Spain and Catalonia, if the professor does not explain the contents in the classroom, they feel as if they did not give a class, even if that is not the case.

Table 6 Interest in the course

\begin{tabular}{|c|c|c|c|c|}
\hline Dimension 5. Interest in the course & Strongly agree & Agree & Disagree & Strongly disagree \\
\hline $\begin{array}{l}\text { When the professor explained how we would be } \\
\text { working I became very interested in the course. }\end{array}$ & $15(57.7 \%)$ & $11(42.3 \%)$ & $0(0 \%)$ & $0(0 \%)$ \\
\hline $\begin{array}{l}\text { I would recommend other students to sign up for } \\
\text { this course. }\end{array}$ & $19(73.1 \%)$ & $7(26.9 \%)$ & $0(0 \%)$ & $0(0 \%)$ \\
\hline
\end{tabular}


Table 7 Comparative chart of students' performance

\begin{tabular}{llll}
\hline Final grade & $2013-2014$ & $2014-2015$ & $2015-2016$ \\
\hline Between 5 and 6 & $3(7.9 \%)$ & $0(0 \%)$ & $0(0 \%)$ \\
Between 6 and 7 & $3(7.9 \%)$ & $1(3.0 \%)$ & $2(6.6 \%)$ \\
Between 7 and 8 & $26(68.4 \%)$ & $2(6.0 \%)$ & $5(16.7 \%)$ \\
Between 8 and 9 & $4(10.5 \%)$ & $14(42.5 \%)$ & $14(46.7 \%))$ \\
Between 9 and 10 & $2(5.3 \%)$ & $16(48.5 \%)$ & $9(30 \%)$ \\
Average grade & 7.5 & 8.6 & 8.4 \\
Total number of students & $38(100 \%)$ & $33(100 \%)$ & $30(100 \%)$ \\
\hline
\end{tabular}

"The difficult part is to remind myself that I shouldn't give students the information as if it was a lecture, which is challenging as we're not used to it." (EN-PROF1)

- Integration of ICTs: professors consider that the tools that the virtual campus provides are very useful for the development of the model.

"I specially value the fact that I can collect and organize the resources in different formats (text, video, etc.) and that I can 'play around' with the forum, tests, or announcements. I believe that the virtual campus is a very important tool in order to work in an organized manner." (EN-PROF2)

- Participation and communication: when lectures are reduced to the minimum and the classroom is organized in small groups, the professor has more time to interact with the students. When trust between students and the professor builds, students relax and feel more confident to ask more questions than if they were listening to a lecture.

"The method allows for a relaxed and familiar climate within the classroom. In fact, I think that this is the part I enjoy the most: I can see the students discussing the topics and getting involved with the activities while they ask me many questions." (EN-PROF2)

- Interest in the course: in line with the opinions expressed by students, the professors observed that students show their enthusiasm to attend the classes. Likewise, the professors noticed that students value the way in which the class is given, and that they also enjoy the practical sessions.

"As a professor you come to realize that if you give them the right opportunities, students get more involved. And we appreciate that, and it also makes us very proud." (EN-PROF1)

\section{Discussion}

The present study brings some insight to the possibilities of the flipped classroom model, both at the faculty and the student levels. The results obtained are in the same line as others similarly concerned with the flipped classroom (Finkel, 2012; Yarbro et al., 2014; Tourón \& Santiago, 2015). Further, the results offer an additional element, which contributes to the field of education, and reaffirms the model.

The study points to the fact that the flipped classroom improves: integration of concepts; participation and communication; students' interest in the course; integration of 
ICTs in the classroom; and academic results. Besides, the model allows for a change in the roles of both professors and students.

Further, we observed that the average grade obtained in the academic year 20132014 was a 7.5, an 8.6 in 2014-1015, and an 8.4 in 2015-2016. These grades confirm the fact already mentioned by Blair et al. (2015) that the model contributes to the improvement of academic results. In addition, we believe that this improvement is not only quantitative. In fact, we believe that the flipped classroom makes students become more aware of the acquisition of the learning competencies.

In line with Shea and Bidjerano (2010) and Shea et al. (2012), the students' empowerment, the joint construction of knowledge and the collaborative work that students carry out are key elements that enrich the model.

This type of innovation requires the professors to rethink the way they organize the class and the classroom. That is, the professors need to: move away from the traditional role of the professor by reducing the time for explanations and increase collaborative spaces by developing projects in the classroom, planning and preparing activities in advance, and expanding the formative space through the ICTs (debates, online activities, shared resources, etcetera), among others.

This is also a model that integrates the ICTs in the teaching-learning process, helps to organize knowledge collectively, puts the students in the center of the process, and teaches basic competencies.

To conclude, we would like to point out that there are other types of studies that could also be implemented in the future. Concrete examples of these would be working with experimental or control groups, or carrying out pre-tests and post-tests. Moreover, we deem necessary to develop similar studies within other academic fields and in other universities. This way, by carrying out thorough studies, we are closer to reaching more definitive conclusions regarding the efficacy of the flipped classroom model. Finally, it would be interesting to analyze the materials and resources used as well as the activities carried out in order to identify those that improved the learning process the most.

Received: 20 October 2015 Accepted: 16 March 2016

Published online: 31 May 2016

References

Abeysekera, L., \& Dawson, P. (2015). Motivation and cognitive load in the flipped classroom: definition, rationale and a call for research. Higher Education Research \& Development, 34(1), 1-14. Retrieved from http://goo.gl/1CaLce. Accessed 5 Mar 2016.

Arthur, L., \& Cox, E. (2014). From evaluation to research. International Journal of Research \& Method in Education, 37(2), 137-150.

Bergmann, J., \& Sams, A. (2014). Flip Your Classroom. Reach Every Student in Every Class Every Day. SM. Retrieved from http://goo.gl/Y1bAWz. Accessed 5 Mar 2016.

Blair, E. Maharaj, C., \& Primus, S. (2015). Performance and perception in the flipped classroom. Education and Information Technologies, 1-18. Retrieved from http://link.springer.com/article/10.1007/s10639-015-9393-5. Accessed 5 Feb 2016

Carballo, A. L. (2014). Reflections on Blended Learning. El Guiniguada, 23, 63-70. Retrieved from http://goo.gl/hmhH2p. Accessed 5 Mar 2016

Del Arco, I., \& Camats, R. (2015). Teachers' training in "flipped classroom". Escuela, monographic, 2015, 16-17.

Finkel, E. (2012). Flipping the Script in K-12. District Administration, 48(10), 28. Retrieved from http://goo.gl/bU6sOq. Accessed 5 Mar 2016.

Flipped Learning Network. (2012). Improve student learning and teacher satisfaction with one flip of the classroom.

Flores, Ò. (2015). To plan a flipped classroom. Escuela, monographic, 2015, 7-8.

Goodwin, B., \& Miller, K. (2013). Evidence on flipped classrooms is still coming in. Educational Leadership, 70(6), 78-80. Retrieved from http://goo.gl/o1l91v. Accessed 5 Mar 2016.

Greene, J.C. (2007). Mixed methods in social inquiry. San Francisco, USA: John Wiley \& Sons.

Moraros, J., Islam, A., Yu, S., Banow, R., \& Schindelka, B. (2015). Flipping for success: evaluating the effectiveness of a novel teaching approach in a graduate level setting. BMC Medical Education, 15(1), 1-10. Retrieved from http://goo.gl/80fFP9. Accessed 5 Mar 2016. 
Navarro, M.N. (2013). M-Learning and uses of tablets and cellulars in classroom. Distractions or stimulations of learning? Praxis investigativa ReDIE, 5(8). Retrieved from http://goo.gl/cA8EcP. Accessed 5 Mar 2016.

Prensky, M. (2010). Digital Natives, Digital Immigrants. S.A.: Distribuidora SEK. Retrieved from http://goo.gl/ibWsHN. Accessed 5 Mar 2016.

Rivera, E. (2015). Using the Flipped Classroom Model in Your Library Instruction Course. The Reference Librarian, 56(1), 34-41. Retrieved from http://goo.gl/KwNAT7. Accessed 5 Mar 2016.

Shea, P., \& Bidjerano, T. (2010). Learning presence: Towards a theory of self-efficacy, self-regulation, and the development of a community of inquiry in online and blended learning environments. Computers in Education, 55(4), 1721-1731. Retrieved from http://dx.doi.org/10.1016/j.compedu.2010.07.017. Accessed 5 Mar 2016.

Shea, P., Hayes, S., Smith, S. U., Vickers, J., Bidjerano, T., Pickett, A., .. \& Jian, S. (2012). Learning presence: Additional research on a new conceptual element within the Community of Inquiry (Col) framework. The Internet and Higher Education, 15(2), 89-95. Retrieved from http://dx.doi.org/10.1016/j.iheduc.2011.08.002. Accessed 5 Mar 2016.

Siemens, G. (2005). Connectivism: A learning theory for the digital age. International journal of instructional technology and distance learning, 2(1), 3-10.

Stufflebeam, D. L., \& Shinkfield, A. J. (1987). Systematic assessment. Guía teórica y práctica. Barcelona: Paidós/MEC.

Tourón, J., \& Santiago, R. (2015). Flilpped Learning model and the development of talent at school. Revista de Educación, 368, 196-231. Retrieved from http://goo.gl/EfzsEy. Accessed 5 Mar 2016.

Tourón, J., Santiago, R., \& Diez, A. (2014). The Flipped Classroom: How to transform the school in a learning space. Grupo Océano.

Yarbro, J., Arfstrom, K. M., McKnight, K., \& McKnight, P. (2014). Extension of a Review of Flipped Learning. Flipped Learning Network, Retrieved from http://goo.gl/jZ2yBf. Accessed 5 Mar 2016.

Submit your manuscript to a SpringerOpen ${ }^{\circ}$ journal and benefit from:

- Convenient online submission

- Rigorous peer review

- Immediate publication on acceptance

- Open access: articles freely available online

- High visibility within the field

- Retaining the copyright to your article

Submit your next manuscript at $>$ springeropen.com 